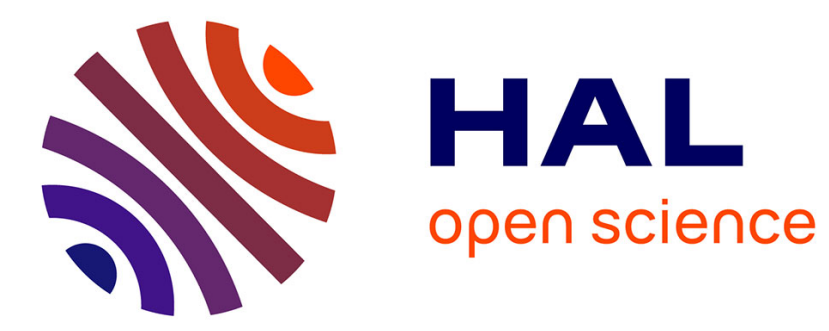

\title{
Mass Customization: Industrial Production Management in Companies Network
}

Sergio Luiz Kyrillos, José Benedito Sacomano, Fábio Papalardo, Francisco Santos Milreu, José De Souza

\section{To cite this version:}

Sergio Luiz Kyrillos, José Benedito Sacomano, Fábio Papalardo, Francisco Santos Milreu, José De Souza. Mass Customization: Industrial Production Management in Companies Network. IFIP International Conference on Advances in Production Management Systems (APMS), Sep 2015, Tokyo, Japan. pp.219-225, 10.1007/978-3-319-22756-6_27 . hal-01417476

\section{HAL Id: hal-01417476 \\ https://hal.science/hal-01417476}

Submitted on 15 Dec 2016

HAL is a multi-disciplinary open access archive for the deposit and dissemination of scientific research documents, whether they are published or not. The documents may come from teaching and research institutions in France or abroad, or from public or private research centers.
L'archive ouverte pluridisciplinaire HAL, est destinée au dépôt et à la diffusion de documents scientifiques de niveau recherche, publiés ou non, émanant des établissements d'enseignement et de recherche français ou étrangers, des laboratoires publics ou privés. 


\title{
Mass customization: industrial production management in companies network.
}

\author{
Sergio Luiz Kyrillos ${ }^{1,2}$, José Benedito Sacomano ${ }^{1}$, Fábio Papalardo ${ }^{1}$, Francisco José \\ Santos Milreu ${ }^{1}$, José Barrozo de Souza ${ }^{1}$ \\ ${ }^{1}$ Paulista University-UNIP, Graduate Program in Production Engineering, Dr. Bacelar St. \\ 1212, São Paulo, Brazil \\ ${ }^{2}$ São Paulo Federal Institute - IFSP, School Engineering, Dr. Pedro Vicente St. 625, São \\ Paulo, Brazil \\ \{Sergio Luiz Kyrillos, kyrillos@ifsp.edu.br\}
}

\begin{abstract}
The goal of this report is to analyse how the mass customization manufacturing strategy is being incorporated by a metal-mechanic company that deals with steel drawing. To sustain the research basis regarding the evaluate data, a case study based on research-action methodology was applied. Customisable goods go through the same production processes as regular products, given the fact that the raw material allows flexibility. Nevertheless, customisable goods are made regarding specific mechanical properties and unique profiles, as rounded with specific diameters, or specials, these coming from laminated bars. This entrepreneur vision seeks to integrate the manufacturing process alterations to as down the line as possible. Customers require products that are not always ready to buy in the necessary quantities and different patterns in steel distribution centres, which have regulations to obey before despatch.
\end{abstract}

Keywords: Business networking 1, Mass customization 2, Production 3.

\section{Introduction}

In this empiric study, the strategic aspects of production and manufacturing are studied from the architecture of companies networks. Under this view, we may conclude that humans, through innovative work and production organisations structures, have become productive entities. We justify this research for the fact that there is a great need to structure the operations and production strategic management model. There are huge gaps in the necessities of production organisations leaderships on conducting the business in the most competitive way as possible.

With that in mind, it becomes relevant for this proposed study to pursue the goal of a management procedure capable of contributing with the production managers of network companies, besides helping to improve the existent production management. In which way can mass customization (MC) be managed and applied in a metal-mechanic industry? What are the inductive requirements to the occurrence of MC on a Production Planning \& Control (PPC) strategic model in companies network (NetC)? The case study, as it 
shall be proven, will assure that the implementation of $\mathrm{MC}-$ an evolution in the way of organising work and production - brings competitive vantages to the productive process.

\section{Bibliographic Review}

According to [7] the industrial production system, understood as the "the group of physical, humane and management procedure elements, designed on a inter-related manner' generating products with aggregated value that surpass the their expenditures, conducting the organization to success.

Due to the intensification of the competition on a global scale, there is a rampant search to aggregate value do the products, as to adequate the productive system to the buyer's necessities besides the pursue of customers' loyalty. The term MC first appeared in 1987 with Stanley Davis in his work "The Perfect Future". MC is understood as the manufacturing system capable of offering personal goods and/or services in large scale, with similar cost of those standard products. Another definition to MC refers to the "ability to offer products and services individually designed to each customer through a highly agile, flexible and integrated system with mass production costs"[3]. According [4] has proposed a PPC based on Manufacturing Management Strategical Paradigms (MaMSPs) and MC should represent a distinctive feature as a competitive advantage and the supply chain must support the demands.

NetC seek to relate the technological level and the productive capacity interacting and offering to the customer a range of products. Actors inserted in a NetC are supporters, supposed to perform business negotiations seeking to bring goods and services nearer the final customer. In a network of companies there is cooperation among the companies and also the collaboration to pursue objectives that wouldn't be accomplished independently. Networks are not a new concept to business. In fact, ever since businesses seeking profit have appeared, cooperative efforts were made to develop products together, and allow valuable support and services to one another. This involves raising the competitiveness, reducing costs, stimulating new business opportunities, reaching for great vantages, gaining velocity in the process and satisfactorily answering customers' needs. NetC PPC contains activities focused in the collective character result, organising efforts to conduce to sucess chain. Companies that develop rapid answer to high quality and personalised products demand shall have competitive advantage [5]. Latu sensu, PPC, refers to the production management of goods and services that will be 
available in future opportunities. The production is the focus of the activities constituted by management structures that stimulate the cooperation inside the company and from company to company.

In this sense is Necessary to integrate flexible technologies to the needs of actors within a reasonable period. These assumptions require new forms of work and organisation in this modern society. Manufactures, particularly agile manufacturing, require designs with integrated and interdependent systems prioritizing interfaces between people, machines and between people and machines. Manufacturing processes have sought to respond with increasing speed to their markets as compared to the responses obtained twenty years ago. This evolution took place due to the rapidly changing economy to a global process in which characteristics can often be expressed in highly complex models. The so-called "competitiveness" is the answer that businesses seek in order to remain at the forefront their markets [2]. Manufacturers throughout the world are facing major new challenges, including shorter product life cycles and increasing competition. The MC is a option to fight that cases. Companies strive to rationalize engineering design, manufacturing, and support processes and to produce a large variety of products at lower costs, modularity is becoming a focus [8]. [10] analyzed and showed a provides a guidelines for managers regarding how to strategically adjust their systems and investments to exploit the complementarities and synergies among the practices for MC development

\section{$3 \quad$ Methodology and case study}

\section{1 - Company info}

Seeking earning more attractive profits and moving away from the traditional format of obtaining margin, which is based on economies of scale, it was noticed a consumer niche products that are not always available in warehouses of iron and steel distributors. Consumers looking for products that can meet their expectations regarding the manufacturing of mechanical parts and components of machines with different applications and constructive characteristics. These are willing to pay higher prices for products made of steel and when subjected to plastic deformation change their mechanical properties depending on the severity of the forming process, the submission of the same to thermal intermediaries or thermochemical treatments.

The search for suppliers that meet the required technical specifications and in adequate quantities has been noticed that within the companies. In steel network chain it is possible to implementation of drawing lines with different 
profiles (square, round, hexagonal, special cross-sections). A relevant and motivating fact to the implementation of MC refers to the involvement of direct customers as well as customers of those who may not be the end users of the products or services of the transaction throughout the production chain. The operations that interfere with the formation of $\mathrm{NetC}$ - permeated by suppliers, for suppliers of suppliers, clients and customers of customers create supply chains and bring suppliers flow of goods to customers, while the links in this network send manufacturing orders and requests. The two-way traffic - with goods and information following in opposite directions - has been accentuated causing significant changes in production processes including outsourcing the production of components, flexible manufacturing and intensive use of information technology. Thus, instabilities of economic and financial order contributed to erode mass production systems and highlight new conditions companies moulded contours inserted in the global market.

\section{2 - The process of steel drawing, and competition analysis}

Wire-drawing consists in making the wire rod (raw material: rods obtained by hot rolling) is forced to pass (by tensile stress) through a calibrated orifice (ring). This is a mechanical forming process by plastic deformation; a common procedure for producing steel wires. Changing the calibrated orifice of the die allows the shaping of different profiles. The drawing process the achievement of wires with controlled diameters and well-defined mechanical properties. In traction banks, it is possible to stretch bars to make special profiles.

Using the current concept of MC, it is clear that in a globalised world extremely consumerist and utilitarian - all 'ends' tend to have short durations, since the goods have high and induced obsolescence, being the new manufactures the means that are used to other 'ends'. In the high performance parts manufacturing segment, from drawn steel, the material used in addition to meeting specific technical features should allow the identification of very rigid mechanical properties and surface finish (polished drawn, rectified, peeled).

The maintenance of close contact between the commercial area of drawbenches with customers allows the construction of a communication channel which significantly eliminates losses with materials that do not meet requirements relating to the production process. This interface avoids waste, creates savings in project and process, reduces processing time and parts and increases the production. Three factors interfered in the studied manufacturing 
for it to undertake efforts to implement differentiated lines from this strategic model of manufacturing management.

1. Reliability in the organization information technology system and organised partner network that delivers a information flow.

2. Implementation of a manufacturing system based on the flexibility of the existing lines to enable direct materials for the drawing of steel with different diameters, mechanical properties and profiles, so that there is no idle capacity in processing lines.

3. PPC strongly committed to the time dimension, since it is unacceptable for an activity to add cost at the expense of added value.

For those who observe this case casually, this research ends here. However, transformations of economic order and character management involving production chains, can push into the abyss companies unable to accept the need to serve customers seeking flexibility and functionality order to optimize the performance of their products and see their needs met in terms of price and facilitation of production processes.

In this sense, there is a need to consider the whole post production network once you understand everything you comprehend why customers and suppliers act the way they act. This results from the fact that the competitive advantages, such as reducing costs, reprogramming production processes, increased productivity and profitability will be a consequence of a customized service. Another factor that arises from that is that when we identify our relevant nodes in the network, we will have the key to understanding the PPC in enterprise networks. To obtain relevant data and to justify the implementation of mass customisation in a company in the manufacturing segment, we seek factors present in process capable to tailor high production process, low cost, integration and flexibility in the chain.

Making use of the theory, to improve aspects of reality, and combining aspects of theory to practical application the problem involving this article has been treated by Competitive Analysis Methodology and Technology - CAMT - which focuses on developing better conditions to the production units, as regards the organization of production;[1] note that "assumptions related to the development and implementation of CAMT sending organizational competitiveness (focusing on individual companies) and inter-organizational (which deals with inter-company networks)". The application of the methodology CAMT follows the guidance of the action-research from [9] it capture information that can combine the concepts "theory-application" for validation in practice. 


\section{4 - Case analysis and discussion}

The strategy for the MC to the case in question begins by a market research of the company products that are already being produced (with changes to existing ones) and new ones (from the specific raw material).

Sales compile the projection of traded items. After, PPC and Finances prepare the budget for production and costing, and together seek to optimize results with the shortest time (value addition and receiving cash in the shortest time possible) all based on the quantities of products to be produced considering the installed capacity; from then, the detail process is triggered, which is enabled by the engineering for existing products with the necessary changes or new products that are produced from the acquisition of raw material (wire $\mathrm{rod} /$ rolled bars) obtained from steel companies or its distributors.

Considering the modeling expressed in Figure 1 below, it is understood that a PPC designed under the form of network involves the most fundamental economic principles, should predict and provide those involved in supply chains so that all those present agents are understood as productive entities that contribute to the strengthening of the network operations, making the business network to be viable through the value network that has a physical network as basic support.

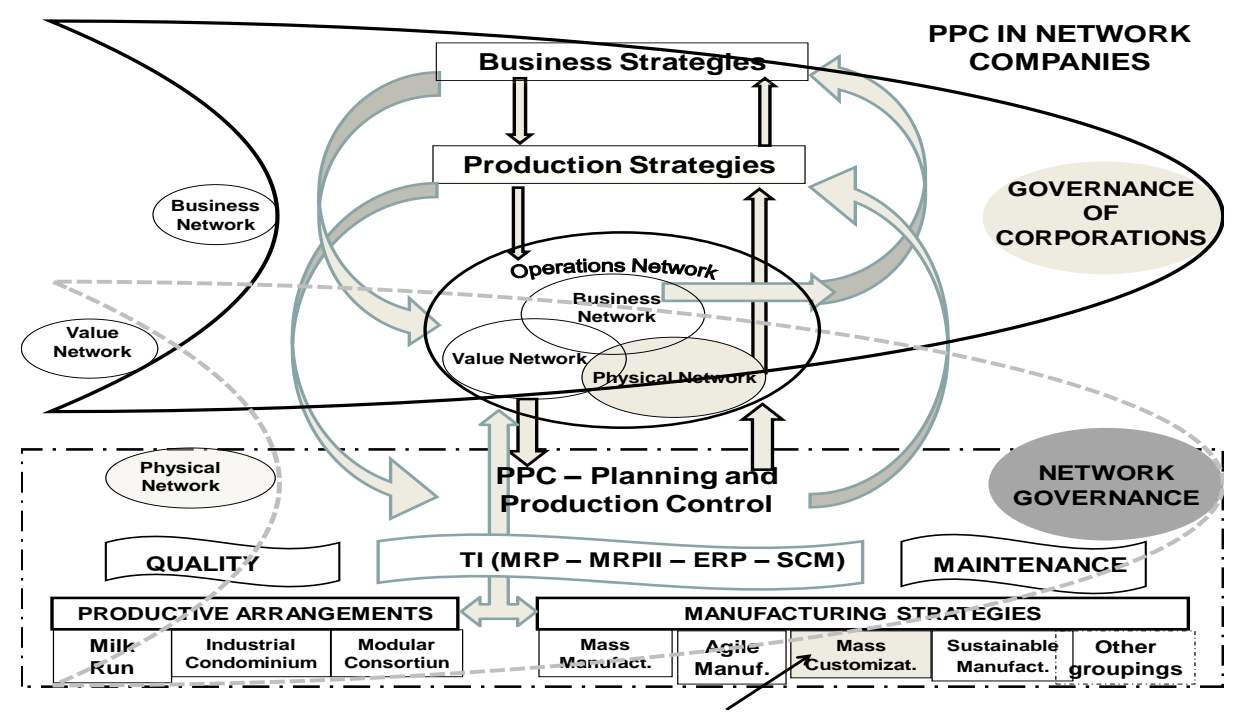

Fig. 1. PPC in NetC. Source: Authors based on conceptual map [6] 
The latter - the physical network - is indeed where the productive activities have been actualised. It gives priority to the interrelationship of the inputs flow, capital and technologies that enable the acquisition on the format, on time, in the right quantity, at the opportunity and in the place required by customers. The governance of the corporation (solid line capsule) involves several decisions to be made into a productive character development and from it decisions with increasing complexity can arise.

The governance of the network (grey dash line capsule) involves the management of the physical network with the required specification of production methods, adequacy of the facilities, product quantity and compatible equipment. This requires a management that is involved with the PPC. In Figure 1 we can see that the MC is a procedure able to support the development in screen. Each organization has a private communication itself to the manifestation of how the tasks are carried out within the complex relationships that make up the organizational structure.

\section{Conclusions and recommendations}

The finding of a distinct market acquisition of specific products was the promoter to implant a structured management on the MC associated to deficiency of competitors in meeting the needs performance parts manufacturers generated opportunities to drawbenches. In order to become customizable, the company in question has sought to delay most of the drawn production processes. The PPC seeks to integrate to sales on the most downstream.

Considering the time dimension and performing a thorough analysis of the logistics flow efficiency in the organisation. The aim is to fill orders able to add value by standardizing products considered basics and slowing the manufacturing of items ordered for specific latter applications. In order to make the MC possible inductors requirements are to identify the occurrence of manufacturing management in the proposed model. The first relates to the reliability on the system information technology. The other dimension is related to PPC, which must be strongly committed to the time dimension. Excess time generates capital loss in every link of the production chain. Strategically management implies in transforming the productive time in resources that increase cash availability. Nowadays, the companies are feeling pressure from both the world market and also, either internally, by the diversity of the national market or by international organizations that have business in the country. These movements led to the introduction of new forms of industrial organization in Brazilian manufacturing systems, stimulating the questioning of the existing 
standards. However, the Brazilian conditions, such as high interest rates, instability in demand, restricted consumer market, among other things require greater adaptation to changes. Brazil and our companies have peculiar characteristics regarding the conditions of other countries where these new forms of industrial organization have also emerged. This study of MC is an effort to define new standards, relevant to the improvement of business of an individual firm, and its integration to network practiced business processes. This study does not end here; it is the basis for others who seek to analyze PCP in NetC. The picture showed in this work was classified as complex, since the search for competitiveness in a dynamic environment permeated by and intensified by global competition demands requires: business reflection, environment context analysis and intellectual daring, all simultaneously. The study deals with the MC strategy from the perspective of PPC in NetC as identified in the conceptual map shown in Figure 1. This way of conceptualizing the PPC differs from the conventional PPC concepts based, including the understandings of Make to Order (MTO) and Engineering to Order (ETO).

\section{References}

1. Barbosa, F. A.; Sacomano, J. B.; Porto, A, J. V.: Metodologia de análise para redes interorganizacionais: competitividade e tecnologia. Revista Gestão e Produção, may-aug 14, 411-423. São Carlos, SP (2007)

2. Boer,W. ; Fusco, J.P.A.,Produtividade $x$ valor agregado na manufatura: Uma revisão da literatura. Revista Brasileira de Tecnologia Agroindustrial. 02/01, 35-48. Ponta Grossa, PR (2008).

3. Da Silveira, G.; Borenstain, D.; Fogliatto, F.S.: Mass Customization: Literature review and research directions. International Journal of Productions Economics. 72, 1-13 (2001).

4. Godinho Filho, M.; F.C.F.: Manufatura ágil e customização em massa: Conceitos, semelhanças e diferenças. R. Adm. 41 /01, 81-95. São Paulo, SP (2006).

5. Iacocca Institute. Mass Customization. Office of International Affairs Iacocca Institute Professional Education at Lehigh University (2009) http://www.iacocca-lehigh.org/ 19.01.2015

6. Kyrillos, S. L.: Fatores determinantes para o planejamento e controle da produção em redes de empresas: Estudo exploratório em unidades de negócios do segmento metalmecânico. Tese (doutorado). Programa de Pós-graduação em engenharia de produção. Universidade Paulista, SP (2011).

7. Maccarthy, B.L.; Fernandes,F.C.F.: A multi-dimensional classification of production systems for the design and selection of production planning and control systems. Production Planning \& Control 11/5, 481-496. London (2000).

8. Shaik, A.M; Rao, V.V.S.K; Rao, C.S.: Development of modular manufacturing system - a review. Int J Adv Manuf Technol. 76, 789-802. Springer, Verlag-London (2015).

9. Thiollent, M. Pesquisa-ação nas organizações. Atlas, São Paulo, SP (2007).

10. Zhang, M.;Zhao, X.; Qi, Y. The effects of organizational flatness, coordination, and product modularity on mass customization capability. Int.J.ProductionEconomics 158, 145-155. Elsevier, BV (2014). 